\title{
Viability of Litter-Stored Quercus falcata Michx. Acorns after Simulated Prescribed Winter Burns
}

\author{
Michael D. Cain and Michael G. Shelton \\ USDA Forest Service, Southern Research Station, P.O. Box 3.516, Monticello, Arkansas 71656 \\ Tel. 870367 3464; Fax 8703671164
}

\begin{abstract}
Partially stratified (11 days) southern red oak (Quercus falcata Michx.) acorns were placed at three depths in a reconstructed forest floor and subjected to simulated prescribed winter bums. Within the forest floor, acorns were placed within the L layer, at the upper-F/ lower-F interface, and at the lower-F/mineral-soil interface. Winds for a backfire and headfire were generated by electric box-fans. After the bums, acorns were transferred to moist sand flats, stratified for an additional 16 days, then assessed for viability during a 45-day germination test. As depth within the forest floor increased, germinative capacity of acorns increased. All acorns placed within the L layer during prescribed burning failed to germinate. Germinative capacity of acorns placed at the upper-F/lower-F interface was lower $(P=0.03)$ in the backfire $(8.75 \%)$ than in the headfire $(55.00 \%)$. At the lower- $\mathrm{F} / \mathrm{mineral}$-soil interface, there was no difference $(P=0.09)$ in germinative capacity between backfire $(92 \%)$ and headfire $(89 \%)$, and their mean was no different $(P=0.26)$ than the $93 \%$ achieved by unburned control acorns.
\end{abstract}

Keywords: Southern red oak; natural regeneration; seed bank; southern Arkansas.

\section{Introduction}

Forestry benefits from prescribed burning include: site or seedbed preparation, control of unwanted vegetation, disease control, thinning of dense young pine stands, increased growth and yield of pines, and improvement of wildlife habitat (Davis 1959, Crow and Shilling 1980). Therefore, prescribed burning has been widely used in southern pine management. Concomitantly, fire can also be used in the management of hardwood stands; but its use lags behind that in pine stands and the effects are less well known. Exclusion of fire or other disturbances from mature oak stands may alter the ecology of the stands to the detriment of oak regeneration (Little 1974, Watt et al.
1993). Because oak seedlings are generally less susceptible to root-kill by fire than other species, periodic burning may play a major role in promoting advanced oak regeneration (Van Lear and Waldrop 1989). Fire should favor oaks because of their thick bark, sprouting ability, resistance to rotting after scarring, and the suitability of fire-created seedbeds for acorn germination (Abrams 1992).

Prescribed burning can have a positive effect on wildlife habitat by increasing certain essential nutrients and palatability of forage, initially reducing leafy biomass followed by increases, and initially decreasing fruit yields followed by increases (Landers 1987). A negative effect of burning on wildlife habitat is the purported destruction of disseminated hard mast such as acorns (Korstian 1927). Acorn loss would negatively impact a preferred food source for important game species like the gray squirrel (Sciurus carolinensis), white tailed deer (Odocoileus virginianus), and eastern wild turkey (Meleagris gallopavo silvestris) (Byrd and Holbrook 1974). Consequently, it is important to determine the effects of prescribed fire on survivability of acorns in the forest floor.

Southern red oak (Quercus falcata Michx.) was chosen for this investigation because the species occurs throughout the Southeastern U.S. in mixed stands with other hardwoods and with the southern yellow pines (Pinus spp.). Observational data suggest that oak mast in the duff of the forest floor can be destroyed by hot surface fires, but light (cool) surface fires may simply expose recently fallen acorns (Harlow and Van Lear 1989). Although acorn loss by fire is a reasonable assumption, such reports have been based on anecdotal observations rather than definitive research. The purpose of the present investigation was to experimentally determine if southern red oak acorns could survive prescribed winter burns depending upon (1) acorn placement in a reconstructed forest floor and (2) fire intensity using a simulated headfire and backfire. 


\section{Methods}

The study was located on forest lands of the School of Forest Resources, University of Arkansas at Monticello. The study site is situated in the West Gulf Coastal Plain at $91^{\circ} 46^{\prime} \mathrm{W}$ and $33^{\circ} 37^{\prime} \mathrm{N}$. Elevation of the forested area is $98 \mathrm{~m}$ with rolling topography. The soil is a Sacul loam (clayey, mixed, thermic, Aquic Hapludult), described as a moderately well drained upland soil with a site index of $24 \mathrm{~m}$ for loblolly pine at age 50 (USDA 1976). The growing season is about 240 days, and annual precipitation averages $134 \mathrm{~cm}$ with seasonal extremes being wet winters and dry autumns.

Within a pine seed-tree area, we prepared a $10-\mathrm{m}$ by 10-m study site by using a small tractor and push-blade to remove vegetation and roots, thereby exposing mineral soil. Within the cleared area, two $1 \mathrm{~S}-\mathrm{m}$ by 2 . 1-m beds were framed with steel railings, and the soil in each bed was leveled with hand tools. The leveled soil was allowed to settle four weeks at which time we reconstructed a forest floor within each bed using procedures developed by Shelton (1995). A reconstructed forest floor ensured uniform fuel conditions for burning (Hungerford et al. 1995) as well as uniform litter layers for acorn placement.

In mid-February 1996, six days after a rain event and before the day of burning, we obtained undisturbed forest floor material from beneath a closed forest canopy, 1 $\mathrm{km}$ from the burn site. In that area, basal area from oaks averaged $14.5 \mathrm{~m}^{2} / \mathrm{ha}$, basal area from pines averaged 13.0 $\mathrm{m}^{2} / \mathrm{ha}$, and basal area from other hardwoods averaged 4.6 $\mathrm{m}^{2} / \mathrm{ha}$. The forest floor was typical of similar stand conditions found elsewhere in the South (Switzer et al. 1979). To facilitate reconstruction, we collected the forest floor in three layers - L, upper F, and lower F using $0.12 \mathrm{~m}^{2}$ sampling frames. The $\mathrm{L}$ layer refers to the litter layer consisting of unaltered dead remains of plants (Pritchett 1979). The fermentation (F) layer was immediately below the L layer and consisted of fragmented, partly decomposed organic materials that were sufficiently preserved to permit identification as to origin (Pritchett 1979). For this experiment, we subdivided the $\mathrm{F}$ layer into upper and lower zones based on visual evidence of decay. The undisturbed L layer averaged $12 \mathrm{~mm}$ in thickness, the upper $F$ layer averaged $6 \mathrm{~mm}$, and the lower $\mathrm{F}$ layer averaged $17 \mathrm{~mm}$. These three layers were transferred from the undisturbed forest floor in paper bags and reconstructed on the two burn beds during the day of removal, which was less than 24 hours before the burns.

Within each bed, a $0.95-\mathrm{m}$ by $1.50-\mathrm{m}$ interior plot was subdivided into twelve $0.12 \mathrm{~m}^{2}$ cells (replications) for placement of the reconstructed forest floor and acorns. One burn bed was assigned a simulated headfire treatment and the other bed a simulated backfire. Our premise in using one bed for each burn type was that sampling error would adequately capture experimental error. Wind for the simulated headfire and backfire was provided from two $0.56-\mathrm{m}^{2}$ electric box-fans positioned side-by-side. Fan-blade rotation was varied during burning to maintain a constant wind speed at the fire front. The experiment was a randomized complete block design with four replications of the three forest floor layers within each burn bed. Blocking was based on distance from the box-fans.

Acorns for the study were collected in late November 1995 from beneath a mature, open-grown southern red oak (56 cm in diameter at $1.37 \mathrm{~m}$ above ground) located about $3 \mathrm{~km}$ from the burn site. Acorns that floated in a water bath were discarded. Acorns that did not float were considered sound and were subsequently stored at $4^{\circ} \mathrm{C}$ until being placed in moist sand for stratification at $4{ }^{\circ} \mathrm{C}$ in early February 1996. These acorns averaged $12 \mathrm{~mm}$ in diameter.

For each replicated cell in the burn beds, we used 20 acorns that had an average moisture content of $56 \%$ (ovendry basis). Partially stratified acorns were transferred to the center of each burn cell and placed so that the embryonic axis was parallel to one of three layers within the reconstructed forest floor - within the L layer, at the upper-F/lower-F interface, and at the lower-F and mineralsoil interface (Figure 1). Dry weight of the L layer averaged $2.94 \mathrm{Mg} / \mathrm{ha}$ of which $75 \%$ was oak litter, $22 \%$ was pine litter, and $3 \%$ was woody debris.

Prescribed bums were conducted on February 13, 1996 (Table 1). Wind speed was determined from an electronic Turbo-Meter@wind speed indicator'. While bums were in progress, flame lengths were ocularly estimated to the nearest $15 \mathrm{~cm}$ and recorded. Fireline intensity was calculated from flame lengths in accordance with Byram (1959).

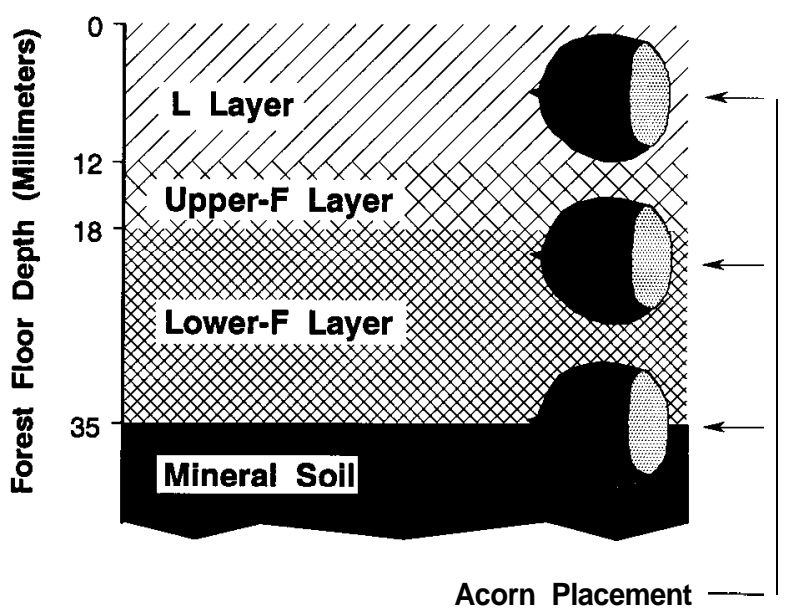

Figure 1. Before prescribe burning, southern red oak acorns were placed at three depths within the forest floor-within the $\mathrm{L}$ layer, within the $\mathrm{F}$ layer, and at the lower- $\mathrm{F}$ and mineral-soil interface.

\footnotetext{
${ }^{1}$ The use of firm or trade names is for reader information and does not imply endorsement of any product or service by the U.S. Department of Agriculture.
} 
Table 1. Fuel and weather conditions during simulated prescribed winter bums in southern Arkansas, USA.

\begin{tabular}{|c|c|}
\hline \multirow[b]{2}{*}{ Fuel and weather variables } & Burn type \\
\hline & Headfire Backfire \\
\hline Date of bums & February 13, 1996 \\
\hline Days since last precipitation & $-6--$ \\
\hline Time of burning (hrs. CST) & $1130 \quad 1140$ \\
\hline Dry bulb temperature ("C) & $--17--$ \\
\hline Relative humidity (\%) & $--25--$ \\
\hline Wind direction & - - South - - \\
\hline Wind speed' $\left(\mathrm{km} \mathrm{h}^{-1}\right)$ & $--6.4 \quad-$ \\
\hline \multicolumn{2}{|l|}{ Forest floor moisture (\%) } \\
\hline L layer' & $--22--$ \\
\hline Upper F & $--39--$ \\
\hline Lower F & $-\quad 111-\ldots$ \\
\hline \multicolumn{2}{|l|}{ Forest floor weight $\left(\mathrm{Mg} \mathrm{ha}^{-1}\right)$} \\
\hline L layer & $-2.9--$ \\
\hline Upper F & $--2.7-\ldots$ \\
\hline Lower F & $--13.6-$ \\
\hline Mean fireline intensity' $\left(\mathrm{kW} \mathrm{m}^{-1}\right)$ & $36 \quad 8$ \\
\hline Rate of spread $\left(\mathrm{m} \mathrm{h}^{-1}\right)$ & 54 \\
\hline
\end{tabular}

${ }^{1}$ Wind speed generated by two electric box-fans.

2 Fine-fuel moisture.

${ }^{3} \mathrm{I}=5.67 \mathrm{~L}_{\mathrm{f}}{ }^{2.17}$, where $\mathrm{L}_{\mathrm{f}}=$ Ocular estimates of flame length.

Immediately after burning, residual litter was measured by taking four $0.1-\mathrm{m}^{2}$ samples within each burn bed and obtaining oven-dry weights. We removed the acorns from the burn beds and transferred them to individual $20-\mathrm{cm}^{3}$ cells filled with moist vermiculite in plastic germination flats for an additional 16 days of stratification before germination. Acorns were covered to a depth of $1 \mathrm{~cm}$ with vermiculite. The germination test ran for 45 days during which acorns were exposed to 10 hours of full-spectrum fluorescent light and 14 hours of darkness during each 24 hours. Temperature in the germination room was maintained at 24 "C. Germination was considered complete when the oak epicotyl was at least $1 \mathrm{~cm}$ in height above the vermiculite.

Analysis of variance was used to compare germinative capacity of acorns relative to their location within the forest floor and bum type (SAS Institute, Inc. 1989). Germination percent was analyzed following arcsine squareroot proportion transformation, but only nontransformed percentages are reported. Orthogonal contrasts were used to partition mean differences among acorn locations within the forest floor as follows: $L$ versus $F_{U} F_{L}+F_{L} S$, and $F_{U} F_{L}$ versus $F_{L} S$. $L$ is the L layer, $F_{U}$ is the upper-F layer, $F_{L}$ is the lower-F layer, and $\mathrm{S}$ is mineral soil. A second analysis of variance was used to compare the germinative capacity of acorns from the Headfire $F_{L} S$ and Backfire $F_{L} S$ interface to that of unburned control acorns. In orthogonal contrasts, significance was accepted at the $\alpha=0.05$ probability level.

\section{Results and Discussion}

Once burning was complete, it was obvious from the charred litter that both the headfire and backfire completely traversed the burn beds, leaving no unburned gaps. Although no acorns were completely destroyed by the burns, none subsequently germinated if they had been placed within the L layer during burning (Table 2).

In analysis of variance (Table 3 ), the burn-type $\mathrm{x}$ acorn-location interaction was significant $(P<0.01)$ because the degree of change in germinative capacity of acorns between forest-floor layers was greater in the backfire than in the headfire. Fireline intensity of the simulated headfire averaged $41 / 2$ times that of the backfire (Table 1), with fuel consumption being 7.3 $\mathrm{Mg} / \mathrm{ha}$ by the headfire and $8.4 \mathrm{Mg} / \mathrm{ha}$ by the backfire. After the headfire, acorn germination averaged $48 \%$, which was 14 percentage points better $(P<0.01)$ than acorn germination following the backfire (Table 3). This difference in germination was attributed to the somewhat greater heatshield provided by unburned litter in the headfire - i.e., postburn litter weights averaged $11.9 \mathrm{Mg} / \mathrm{ha}$ after the headfire versus $10.8 \mathrm{Mg} / \mathrm{ha}$ after the backfire. In a review of the literature, Alexander (1982) reported that responses by minor vegetation and seedbed conditions for tree regenera-

Table 2. Germinative capacity of southern red oak acorns placed at three depths within the forest floor during simulated prescribed bums.

\begin{tabular}{|c|c|c|c|c|}
\hline \multirow[t]{2}{*}{$\begin{array}{l}\text { Acorn location } \\
\text { during prescribed bums }\end{array}$} & \multicolumn{2}{|c|}{$\begin{array}{l}\text { Incomplete' acorn } \\
\text { germination } \\
\text { by bum type }\end{array}$} & \multicolumn{2}{|c|}{$\begin{array}{l}\text { Normal }^{2} \text { acorn } \\
\text { germination } \\
\text { by bum type }\end{array}$} \\
\hline & Headfire & Backfire & Headfire & Backfire \\
\hline & \multicolumn{4}{|c|}{$--\cdots------$ Percent ------} \\
\hline Unburned control' & \multicolumn{2}{|c|}{$--4.2--$} & \multicolumn{2}{|c|}{$----92.7----$} \\
\hline L layer & 0.0 & 0.0 & 0.0 & 0.0 \\
\hline Upper-F/Lower-F interface & 2.5 & 0.0 & 55.0 & 8.8 \\
\hline Lower-F/Mineral-soil interface & 5.0 & 2.5 & 88.8 & 92.5 \\
\hline
\end{tabular}

'Only the radicle developed without an epicotyl during the 45-day germination test.

${ }^{2}$ Both epicotyl and radicle developed during the 45-day germination test.

${ }^{3}$ Germination data for unburned controls are presented here solely for comparison purposes. 
T able 3. Analysis of variance for germinative capacity of southem red oak acorns by simulated bum type and acorn location within the forest floor.

\begin{tabular}{|c|c|c|c|}
\hline Source of variation & $\begin{array}{l}\text { Degrees of } \\
\text { freedom }\end{array}$ & $\begin{array}{l}\text { Mean } \\
\text { square }\end{array}$ & $P>\mathrm{F}$ \\
\hline Block & 3 & 0.0069 & $0 . \overline{73}$ \\
\hline Bum type' & 1 & 0.2183 & $<0.01$ \\
\hline Acorn location in forest floor ${ }^{2}$ & 2 & 3.2413 & $<0.01$ \\
\hline$\left(\mathrm{L}\right.$ vs $\mathrm{F}_{\mathrm{V}} \mathrm{F}_{\mathrm{L}}+\mathrm{F}_{\mathrm{L}} \mathrm{S}$ & 1) & 4.2464 & $<0.01$ \\
\hline$\left(F_{U} F_{L} \vee S F_{L} S\right.$ & 1) & 2.2362 & $<0.01$ \\
\hline Bum type $\mathrm{x}$ Acorn location & 2 & 0.2970 & $<0.01$ \\
\hline Error & 15 & 0.0159 & \\
\hline
\end{tabular}

${ }^{1}$ Headfire versus backfire.

${ }^{2} \mathrm{~L}$ is the Litter layer, $\mathrm{F}_{\mathrm{U}} \mathrm{F}_{\mathrm{L}}$ is the Upper-F/Lower-F interface, and $\mathrm{F}_{\mathrm{L}} \mathrm{S}$ is the Lower-F/Mineral-Soil interface.

tion following a fire are directly influenced by depth of the burn.

After the 45-day germination test (Table 2), germinative capacity for the unburned control acorns averaged $92.7 \%$. The proportion of viable acorns within the upper-F/lower-F interface, at $18 \mathrm{~mm}$ within the forest floor, varied from $8.8 \%$ in the backfire to $55.0 \%$ in the headfire (Table 2), and the difference was significant $(P=0.03$, MSE $=0.0480$, ANOVA not presented). At that depth, an additional $2.5 \%$ of acorns in the headfire had incomplete germination (e.g., radicle emergence with no epicotyl).

In these experimental prescribed burns, the lower-F/ mineral-soil interface (Figure 1) produced the highest germination of acorns. For acorns placed at this location, germinative capacity ranged from $89 \%$ in the headfire to $92 \%$ in the backfire (Table 2). Survival of acorns at this depth was mainly attributed to high moisture content (111\% on a dry-weight basis) of the lower-F layer (Table 1) which prevented consumption of the detritus by the fires and moderated their heat. Hartford and Frandsen (1992) reported that moist duff $(60 \%$ to $80 \%$ moisture content) gave considerable protection from mineral soil heating in surface fires. In the present study, germinative capacity of acorns placed at this lower depth in the forest floor averaged 59 percentage points higher $(P<0.01)$ than acorns that remained viable at the upper-F/lower-F interface (Tables 2 and 3).

In a separate statistical analysis (Table 4), germinative capacity of acorns from the lower-F/mineral-soil interface was compared between headfire and backfire and found to be nonsignificant $(P=0.09)$. These data were pooled and compared to the germinative capacity of unburned control acorns, and the difference was also nonsignificant $(P=0.26)$.

This study has demonstrated that southern red oak acorns are not likely to survive prescribed winter burns if they are located within the upper litter layer of the forest floor. Although killing of plant tissue has been reported to occur at about $49{ }^{\circ} \mathrm{C}$ (Davis 1959), both temperature and its duration are important. On these $1.5-\mathrm{m}$ by $2.1-\mathrm{m}$ beds, we conducted followup headfire and backfire test bums using Tempil ${ }^{\circledR}$ temperature indicator pellets. (Big Three Industries, Inc.; South Plainfield, NJ) placed on a reconstructed forest floor consisting mainly of pine litter. These test burns produced temperatures up to $400{ }^{\circ} \mathrm{C}$, but temperatures of $300{ }^{\circ} \mathrm{C}$ were most common.

Operational prescribed winter burns have been conducted on sites with weather conditions similar to those described in this paper but with fuels mainly of pine litter (Cain 1993). In those burns, fireline intensities were greater (163-464 $\left.\mathrm{kW} \mathrm{m}^{-1}\right)$, fine-fuel moisture was lower (6-15\%) and wind speeds were higher $\left(5-21 \mathrm{~km} \mathrm{~h}^{-1}\right)$ than reported in the present simulated burns (Table 1). Operational burns on sites where dead hardwood leaves form the principal fuel should burn cooler than where pine litter predominates (Lotti 1956).

In the present study, the fires consumed the L layer of the forest floor and none of the acorns that were placed within that layer subsequently germinated. Southern red

Table 4. Analysis of variance for germinative capacity of unburned southern red oak acorns and those exposed to simulated prescribed burns at the Lower-F/Mineral-Soil interface within the forest floor.

\begin{tabular}{lccc}
\hline Source of variation & $\begin{array}{c}\text { Degrees of } \\
\text { freedom }\end{array}$ & $\begin{array}{c}\text { Mean } \\
\text { square }\end{array}$ & P>F \\
\hline Block & 3 & 0.0077 & 0.07 \\
Treatment' & 2 & 0.0054 & 0.14 \\
$\quad\left(\mathrm{C} v \mathrm{HF}_{\mathrm{L}} \mathrm{S}+\mathrm{BF}_{\mathrm{L}} \mathrm{S}\right.$ & $1)$ & 0.0030 & 0.26 \\
$\quad\left(\mathrm{HF}_{\mathrm{L}} \mathrm{S}\right.$ vs BFF & $1)$ & 0.0077 & 0.09 \\
Error & 6 & 0.0020 & \\
\hline
\end{tabular}

${ }^{1} \mathrm{C}$ is the unburned Control; $\mathrm{HF}_{\mathrm{L}} \mathrm{S}$ is the Headfire Lower-F/Mineral-Soil interface; and $\mathrm{BF}_{\mathrm{L}} \mathrm{S}$ is the Backfire Lower-F/Mineral-Soil interface.

oak acorns were more likely to survive prescribed winter burns when they were located at the forest-floor/mineralsoil interface, as long as moisture content at that depth was $\geq 100 \%$, which would prevent complete consumption by fire. According to Sander et al. (1983), germination and first-year survival are best when acorns are buried about $3 \mathrm{~cm}$ deep in mineral soil. Under natural conditions, oak acorns are buried by blue jays (Cyanocitta cristata) and squirrels (Sciurus spp.) (Van Lear 1991). In the absence of animal activity, recently disseminated acorns will most likely occur at or near the L/upper-F interface in the forest floor because leaves are shed after seedfall, which occurs in September and October for southern red oak (Belanger 1990). 


\section{References}

Abrams, M.D. 1992. Fire and the development of oak forests. Bioscience 42(5): 346-353.

Alexander, M.E. 1982. Calculating and interpreting forest fire intensities. Can. J. Bot. 60: 349-357.

Belanger, R.P. 1990. Quercus falcata Michx. var. falcata, southern red oak (typical), pp. 640-644. In: R.M. Bums and B.H. Honkala [eds.], Silvics of North America, Vol. 2, Hardwoods. U.S. Dep. Agric., For. Serv., Agric. Handb. 654. Washington, DC.

Byrd, N.A. and H.L. Holbrook. 1974. How to improve forest game habitat. For. Manage. Bull., Southeast Area State and Private Forestry, USDA For. Serv., Atlanta, GA. 6p.

Byram, G.M. 1959. Combustion of forest fuels, pp. 61-89. In: K.P. Davis [ed.], Forest fire ontrol and use. McGraw-Hill, New York.

Cain, M.D. 1993. A 1 O-year evaluation of prescribed winter burns in uneven-aged stands of Pinus taeda L. and P. echinata Mill.: woody understorey vegetation response. Int. J. Wildland Fire 3(1): 13-20.

Crow, A.B. and C.L. Shilling. 1980. Use of prescribed burning to enhance southern pine timber production. South. J. Appl. For. 4: $15-18$.

Davis, K.P. 1959. Forest fire control and use. McGraw-Hill, New York. 584 p.

Harlow, R.F. and D.H. Van Lear. 1989. Effects of prescribed burning on mast production in the southeast, pp. 54-65. In: C.E. McGee [ed.], Southern Appalachian Mast Management. Dep. Forestry, Wildlife and Fisheries, Univ. Tenn., Knoxville, TN

Hartford, R.A. and W.H. Frandsen. 1992. When it's hot, it's hot..or maybe it's not! (surface flaming may not portend extensive soil heating). Int. J. Wildland Fire 2(3): 139-144.

Hungerford, R.D., K.C. Ryan and J.J. Reardon. 1994. Duff consumption: new insights from laboratory burning, pp. 472476. In: Proc. 12th Conf. on Fire and Forest Meteorology. Jekyll Island, GA, Oct. 26-28, 1993. SAF Pub. 94-02. Soc. Amer. For., Bethesda, MD.

Korstian, C.F. 1927. Factors controlling germination and early survival in oaks. Yale Univ. Sch. For. Bull. 19. 115 p.

Landers, J.L. 1987. Prescribed burning for managing wildlife in southeastern pine forests, pp. 19-27. In: Managing Southern Forests for Wildlife and Fish. U.S. Dep. Agric., For. Serv., Gen. Tech. Rep. SO-65. South. For. Exp. Sta., New Orleans, LA.

Little, S. 1974. Effects of fire on temperate forests: Northeastern United States, pp. 225-250. In: T.T. Kozlowski and C.E. Ahlgren [eds.], Fire and ecosystems. Academic Press, New York.

Lotti, T. 1956. Eliminating understory hardwoods with summer prescribed fires in Coastal Plain loblolly pine stands. J. For. 54: 191-192.

Pritchett, W.L. 1979. Properties and management of forest soils. John Wiley and Sons, New York. 500 p.

Sander, I.L., C.E. McGee, K.G. Day, and R.E. Willard. 1983. Oak-Hickory. pp. 116-120. In: R.M. Bums [tech. comp.], Silvicultural Systems for the Major Forest Types of the United States. U.S. Dep. Agric., For. Serv., Agric. Handb. 445. Washington, DC.

SAS Institute, Inc. 1989. SAS/STAT user's guide. Version 6, 4th ed. Vol. 2. SAS Institute, Inc. Cary, NC. 846 p.
Shelton, M.G. 1995. Effects of the amount and composition of the forest floor on emergence and early establishment of loblolly pine seedlings. Can. J. For. Res. 25: 480- 486.

Switzer, G.L., M.G. Shelton, and L.E. Nelson. 1979. Successional development of the forest floor and soil surface on upland sites of the East Gulf Coastal Plain. Ecology 60:1 1621171.

USDA. 1976. Soil Survey of Drew County, Arkansas. U.S. Dep. Agric., Soil Conserv. Serv. and Ark. Agric. Exp. Sta. Washington, DC. 86 p. and maps.

Van Lear, D.H. 1991. Fire and oak regeneration in the southern Appalachians, pp. 15-21. In: S.C. Nodvin and T.A. Waldrop [eds.], Fire and the Environment: Ecological and Cultural Perspectives. Knoxville, TN, March 20-24, 1990. U.S. Dep. Agric., For. Serv., Gen. Tech. Rep. SE-69. Southeast. For. Exp. Sta., Asheville, NC.

Van Lear, D.H. and T.A. Waldrop. 1989. History, uses, and effects of fire in the Appalachians. U.S. Dep. Agric., For. Serv., Gen. Tech. Rep. SE-54. Southeast. For. Exp. Sta., Asheville, NC. 20 p.

Watt, J.M., D.H. Van Lear, and J.G. Williams. 1993. Fire in oak ecosystems, pp. 507-510. In: J.C. Brissette [ed.], Proc. 7th Bienn. South. Silvic. Res. Conf. Mobile, AL, Nov. 17-19, 1992. U.S. Dep. Agric., For. Serv., Gen. Tech. Rep. SO-93. South. For. Exp. Sta., New Orleans, LA. 